\title{
Staphylococcus condimenti sp. nov., from soy sauce mash, and Staphylococcus carnosus (Schleifer and Fischer 1982) subsp. utilis subsp. nov.
}

\author{
1 Institut für \\ Lebensmitteltechnologie, \\ Universitat Hohenheim, \\ Garbenstr. 28, 70593 \\ Stuttgart, Germany \\ 2 Lehrstuhl für \\ Mikrobiologie, Technische \\ Universität München, \\ 80290 Munich, Germany
}

\author{
Andreas J. Probst, ${ }^{1}$ Christian Hertel, ${ }^{1}$ Lothar Richter, ${ }^{2}$ Lars Wassill, ${ }^{2}$ \\ Wolfgang Ludwig ${ }^{2}$ and Walter P. Hammes ${ }^{1}$
}

Author for correspondence: Christian Hertel. Tel: +49711 459 4255. Fax: +497114594199.

e-mail: hertel@uni-hohenheim.de

\begin{abstract}
Based on the sequence data of 235 rRNA of Staphylococcus carnosus, Staphylococcus piscifermentans, Staphylococcus aureus and Staphylococcus epidermidis, species-specific probes were constructed. Their application revealed a heterogeneity within 18 strains previously identified as S. carnosus. Strains of this group were selected, and their 235 rRNA sequence was determined. It was revealed that the strains of $S$. carnosus can be placed in at least three sub-groups. This grouping was supported by physiological data and DNA-DNA similarity studies. Based on these results, we propose the new species Staphylococcus condimenti sp. nov. The type strain is $S$. condimenti F-2 ${ }^{\top}$ (= DSM 11674'). The phylogenetic position of the new species within the radiation of other staphylococcal strains is reflected by a 16S rRNA-based tree. Furthermore, it is proposed to designate the new subspecies of Staphylococcus carnosus Schleifer and Fischer 1982, Staphylococcus carnosus subsp. utilis subsp. nov. The type strain of S. carnosus subsp. utilis is SK $11^{\top}$ (= DSM 11676').
\end{abstract}

Keywords: Staphylococcus condimenti sp. nov., Staphylococcus carnosus subsp. utilis subsp. nov., soy mash

\section{INTRODUCTION}

Strains of the species Staphylococcus carnosus were originally isolated from fermenting sausages (17). It has been shown that they exert positive effects on the formation of flavour and the reddening reaction and therefore strains of this species are used as common components in starter cultures for the production of fermented sausage and cured ham (3). In more recent studies $(20,21)$, it was revealed that strains of $S$. carnosus participate in the fermentation of fish and soy sauces in Asia. A closely related group of strains isolated from fermenting fish sauce was characterized and described as the new species Staphylococcus piscifermentans (21). In this communication, we propose an emended classification within the species $S$. carnosus based on DNA-DNA similarity studies as

The EMBL accession numbers for the 165 and 235 rRNA sequences reported in this paper are $Y 15754$ and $Y 15751$ (S. piscifermentans SK $03^{\top}$ ) and $Y 15750$ and $Y 15755$ (S. condimenti), and $Y 15752$ for the partial 235 rRNA sequence (S. epidermidis DSM 20044'). well as $16 \mathrm{~S}$ and $23 \mathrm{~S}$ rDNA sequence analysis in combination with physiological data. Moreover, 23S rDNA-targeted oligonucleotide probes were constructed for the rapid identification of these species and other food-relevant staphylococci such as Staphylococcus aureus and Staphylococcus epidermidis.

\section{METHODS}

Organisms and growth conditions. The bacterial strains investigated and the strains used to construct and evaluate the specificity of the oligonucleotide probes are those compiled in Table 1. Staphylococci, Kocuria varians and Escherichia coli were grown at $37^{\circ} \mathrm{C}$ on Standard I medium (Merck). Lactic acid bacteria were grown anaerobically at $30^{\circ} \mathrm{C}$ on MRS medium (2), with the exception of Tetragenococcus halophilus DSM $20339^{\mathrm{T}}$ and strains of Carnobacterium $\mathrm{sp}$. These strains were cultivated on MRS medium containing 6.5\% NaCl and CASO-yeast medium (Merck), respectively.

Physiological characterization. Physiological characteristics were determined with the aid of the ID 32 STAPH system 
Table 1. Strains and sources of micro-organisms

$\mathrm{T}=$ Type strain. The following strains were used for the evaluation of the probes:

Carnobacterium divergens (DSM 20623 ${ }^{\mathrm{T}}$ ), Carnobacterium piscicola (DSM 20730 ${ }^{\mathrm{T}}$ ), Enterococcus faecalis (DSM 20478 $)$, Escherichia coli $\mathrm{LTH} 1288$, Kocuria varians (DSM 20033 $)$, Lactobacillus curvatus LTH 1432, Lactobacillus pentosus (DSM 20314 ), Lactobacillus plantarum (DSM 20174 ${ }^{\mathrm{T}}$ ), Lactobacillus sakei LTH 677, Leuconostoc carnosum (DSM 5576 ${ }^{\mathrm{T}}$ ), Pediococcus acidilactici (DSM 20284 ), Pediococcus pentosaceus (DSM 20336 $)$, Staphylococcus arlettae (DSM $20672^{\mathrm{T}}$ ), Staphylococcus auricularis (DSM 20609 $)$, Staphylococcus capitis (DSM 20326 ${ }^{\mathrm{T}}$ ), Staphylococcus caprae (DSM 20608 ${ }^{\mathrm{T}}$ ), Staphylococcus caseolyticus (DSM 20597 ${ }^{\mathrm{T}}$ ), Staphylococcus chromogenes (DSM 20454 ), Staphylococcus cohnii (DSM 20260 $)$, Staphylococcus equorum $($ DSM 20674 $)$, Staphylococcus gallinarum (DSM 20610 $)$, Staphylococcus haemolyticus (DSM $20263^{\mathrm{T}}$ ), Staphylococcus hominis (DSM 20328 ), Staphylococcus hyicus (DSM 20459 $)$, Staphylococcus intermedius (DSM 20373 $)$, Staphylococcus kloosii (DSM 20676 ${ }^{\mathrm{T}}$ ), Staphylococcus lentus (DSM 20352 ${ }^{\mathrm{T}}$ ), Staphylococcus saprophyticus (DSM 20229 $)$, Staphylococcus simulans (DSM 20322 $2^{\mathrm{T}}$ ), Staphylococcus warneri (DSM 20316 $)$, Staphylococcus xylosus (DSM 20266 $)$, Tetragenococcus halophilus (DSM 20339 $)$. DSM, DSMZ-Deutsche Sammlung von Mikroorganismen und Zellkulturen; LTH, strain collection of the Institut für Lebensmitteltechnologie, Universität Hohenheim, Germany.

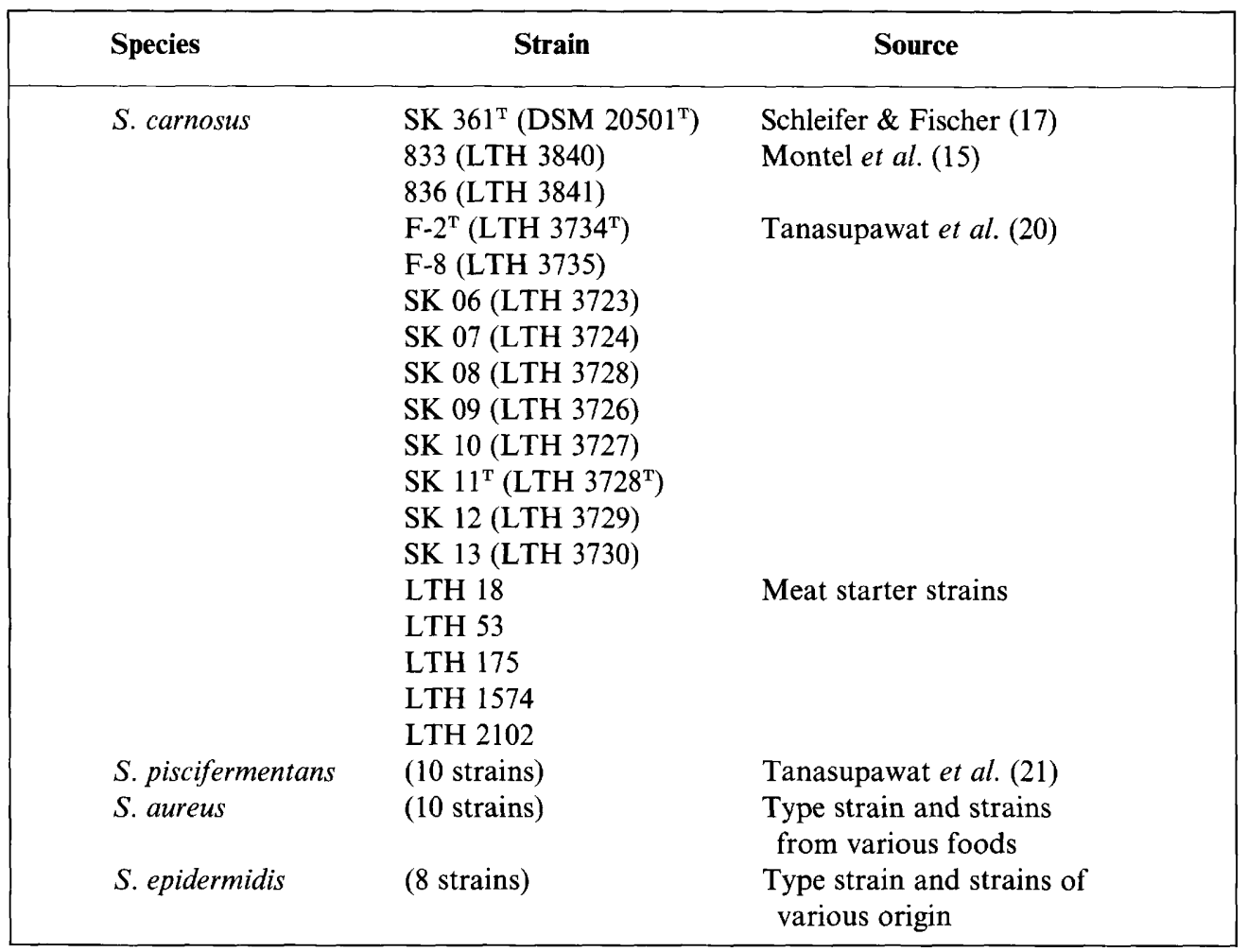

(bioMérieux). Acid production from additional carbohydrates (D-galactose, D-melezitose, D-sorbitol) and glycerol was studied as described by Kloos et al. (8). Catalase activity was detected according to Knauf et al. (9). The sensitivity to lysozyme $\left(400 \mu \mathrm{g} \mathrm{ml}^{-1}\right.$ and $\left.1.6 \mathrm{mg} \mathrm{ml}^{-1}\right)$ and lysostaphin $\left(200 \mu \mathrm{g} \mathrm{ml}^{-1}\right)$ was determined on agar plates (8). Tolerance to $\mathrm{NaCl}$ was examined by incubating for $24 \mathrm{~h}$ on $\mathrm{P}$-agar (8) containing $\mathrm{NaCl}$ at concentrations of $0.5,5,10$ and $15 \%$. Relation to temperature was determined on P-agar at 8,15 , $25,34,42$ and $45^{\circ} \mathrm{C}$. The effect of $\mathrm{pH}$ on growth was investigated under aerobic conditions in P-medium containing $20 \mathrm{mM}$ ammonium citrate adjusted to an initial $\mathrm{pH}$ of $5 \cdot 0$.

Isolation of genomic DNA. Cells of a $5 \mathrm{ml}$ overnight culture were harvested by centrifugation, washed in $2 \mathrm{ml} 5 \times \mathrm{TE}$ buffer (16) and resuspended in $100 \mu 15 \times$ TE buffer containing $100 \mu \mathrm{g}$ RNase $\mathrm{ml}^{-1}$. Staphylococci were lysed by adding $50 \mu \mathrm{l} 10 \mathrm{mM}$ Tris $/ \mathrm{HCl}(\mathrm{pH} \mathrm{7.6)}$ containing $5 \mathrm{mg}$ lysozyme $\mathrm{ml}^{-1}$ (Serva) and $0.5 \mathrm{mg}$ lysostaphin $\mathrm{ml}^{-1}$ (Sigma). All other organisms were lysed by the addition of $50 \mu 1$ of $10 \mathrm{mM}$ Tris $/ \mathrm{HCl}\left(\mathrm{pH} \mathrm{7.6)}\right.$ containing $10 \mathrm{mg}$ lysozyme $\mathrm{ml}^{-1}$. Cell suspensions were incubated at $37^{\circ} \mathrm{C}$ until they became viscous. Thereafter, $150 \mu \mathrm{l} 2 \% \mathrm{SDS}$ and $50 \mu \mathrm{l}$ proteinase $\mathrm{K}$ (18 $\mathrm{mg} \mathrm{ml}^{-1}$; Boehringer Mannheim) were added. The mixtures were incubated for $30 \mathrm{~min}$ at $55^{\circ} \mathrm{C}$. The DNA was purified by repeated phenol-chloroform extractions, precipitated with ethanol and dissolved in $100 \mu 1$ of $1 \times$ TE buffer.

rDNA sequencing. Overlapping stretches of 23S rDNA were amplified with Pwo polymerase (Boehringer Mannheim) in a GeneAmp 2400 PCR system (Perkin-Elmer). PCR frag- 
ments were cloned using the pCR-Script Amp SK(+) cloning kit (Stratagene). Plasmid DNA was isolated from $E$. coli with the aid of Qiagen-tip 100 columns (Qiagen). Sequencing was performed using an AutoRead sequencing kit (Pharmacia) as recommended by the supplier. Sequences were read by an ALF DNA sequencer (Pharmacia) and analysed with DNASIS (Hitachi Europe). 16S rDNA was amplified in vitro and sequenced directly as described previously (18).

Sequence data analysis. The rRNA sequence data were added to alignments of deposited complete primary structures of $16 \mathrm{~S}$ and $23 \mathrm{~S}$ rRNA. Phylogenetic analyses were performed by applying maximum-parsimony and maximum-likelihood approaches on data sets varying with respect to the selection of reference sequences as well as sequence positions. The corresponding tools of the ARB program package (11) were used for alignment, selection of positions according to variability, calculation of similarities as well as tree reconstruction, evaluation and drawing.

Design of species-specific probes. A comparative analysis of aligned 23S rDNA sequences of different staphylococci species revealed regions that were used as target sites for species-specific oligonucleotide probes. To optimize the specificity of the probes, target sites were chosen with respect to the most destabilizing effect of mismatches on the oligonucleotide-DNA hybrid $(7,13)$.

Probe hybridizations. For the application of species-specific oligonucleotide probes, $5 \mu \mathrm{g}$ DNA from each strain was denatured in $0.2 \mathrm{M} \mathrm{NaOH} / 2 \times \mathrm{SSC}$ (16) at $37^{\circ} \mathrm{C}$ for $5 \mathrm{~min}$ and transferred to a nylon membrane (Qiabrane; Qiagen) using a dot-blot apparatus (Schleicher \& Schuell). Subsequently, the DNA was immobilized by incubating at $80^{\circ} \mathrm{C}$ for $1 \mathrm{~h}$. Oligonucleotides were labelled with the $3^{\prime}$-digoxigenin (DIG) oligolabelling kit (Boehringer Mannheim). Hybridizations were carried out as described by the supplier. The membranes were washed twice for $10 \mathrm{~min}$ in $2 \times \mathrm{SSC} / 0.1 \%$ SDS. The temperatures used for hybridization and washing are shown in Table 3. Detection of hybrids was performed using a DIG luminescent detection kit (Boehringer Mannheim). For further hybridizations, oligonucleotides and antibodies were removed by washing the membranes twice in $0.2 \mathrm{M} \mathrm{NaOH} / 0.5 \% \mathrm{SDS}$ at $37^{\circ} \mathrm{C}$ for $10 \mathrm{~min}$. Subsequently, the membranes were washed five times in $2 \times \mathrm{SSC}$ to avoid carry-over of $\mathrm{NaOH}$.

DNA-DNA hybridization. DNA similarity was determined using radioactively labelled genomic DNA of strain $\mathrm{F}-2^{\mathrm{T}}$ as a probe. DNA $(5 \mu \mathrm{g})$ from selected type strains was transferred to and immobilized on a nylon membrane as described above. To determine the accessibility of DNA, hybridization with the radioactively labelled $16 \mathrm{~S}$ rDNA bacterial probe EUB338 (1) was carried out as described previously (6). Radioactive-labelling of probe EUB338 was done with the aid of Ready-To-Go T4 polynucleotide kinase (Pharmacia) and Redivue $\left[\gamma^{32} \mathrm{P}\right]$ ATP (Amersham). Genomic DNA of strain F-2 ${ }^{\mathrm{T}}$ was labelled with a Ready-ToGo DNA-labelling kit and Redivue $\left[\alpha^{32}\right.$ P]dATP. Subsequent hybridization was performed at $68^{\circ} \mathrm{C}$ for $24 \mathrm{~h}$. The membrane was washed twice at $70^{\circ} \mathrm{C}$ for $15 \mathrm{~min}$ in $2 \times$ $\mathrm{SSC} / 0.1 \% \mathrm{SDS}$ and once in $0.1 \times \mathrm{SSC} / 0.5 \% \mathrm{SDS}$ to ensure stringent conditions (23). Autoradiograms were digitized with a flatbed scanner (Hewlett-Packard). The DNA similarities were calculated using WinCam software (Cybertech), taking into consideration the accessibility of immobilized DNA for hybridization (10).

\section{RESULTS}

\section{Design and application of oligonucleotide probes}

To construct species-specific probes, the complete 16S and $23 \mathrm{~S}$ rRNA sequences of strain $S$. piscifermentans SK $03^{\mathrm{T}}$ and parts of the 23S rRNA sequence of $S$. epidermidis (DSM 20044 ${ }^{\mathrm{T}}$ ) were determined by sequencing of in vitro amplified or cloned rDNA. The $16 \mathrm{~S}$ and $23 \mathrm{~S}$ rRNA sequences of $S$. carnosus and $S$. aureus have been described previously (14). The comparison of variable regions of these $23 \mathrm{~S}$ rRNA sequences permitted the construction of specific oligonucleotide probes. The application revealed that probes Stpis2, Staur and Stepi were specific for $S$. piscifermentans, $S$. aureus and $S$. epidermidis, respectively, while probe Stcar2 hybridized with the DNA of only a few strains of $S$. carnosus. Therefore, $16 \mathrm{~S}$ and 23S rRNA sequences of strain $\mathrm{F}-2^{\mathrm{T}}$ as well as parts of the 23S rRNA sequences of strains F-8, SK 06 and SK 12 were analysed, and the results were used to construct probes F2son 2 and Stcar4. By applying probes Stcar2, Stcar4 and F2son2, the strains formerly classified as $S$. carnosus could be allotted to groups F, A and B (Table 2). The specificities of all probes were evaluated with DNA isolated from the staphylococci and type strains of species relevant in fermenting high-protein food substrates. The sequences of all probes and the temperatures used for hybridization and washing are given in Table 3.

\section{DNA similarity}

Quantitative DNA-DNA reassociation studies were performed with DNA of the strains of group F and the type strains of $S$. carnosus and $S$. piscifermentans. As shown in Table 4 , strain $\mathrm{F}-2^{\mathrm{T}}$ exhibited a high level of DNA relatedness with strain F-8, but only low levels with $S$. carnosus SK $361^{\mathrm{T}}(58 \%)$ and $S$. piscifermentans SK $03^{\mathrm{T}}(51 \%)$.

\section{Phylogenetic implications}

It was calculated that the $16 \mathrm{~S}$ as well as the $23 \mathrm{~S}$ rRNA sequences of strain F-2 ${ }^{\mathrm{T}}, S$. piscifermentans $\mathrm{SK} 03^{\mathrm{T}}$ and the type strain of $S$. carnosus (14) share more than 99.9 and $98.9 \%$ overall sequence similarity, respectively. For the small-subunit rRNAs, only one to three base changes were found. On the other hand, 13-29 base changes were detected in the 23S rRNA of these strains, confirming the higher overall fraction of variable residues within large-subunit rRNA sequences $(12,14)$. A $16 \mathrm{~S}$ rRNA-based phylogenetic tree reflecting the position of the strains within the radiation of other staphylococcal strains is shown in Fig. 1.

\section{Cultural and morphological properties}

To support the grouping depicted in Table 2, the strains were studied in more detail. All strains grew well on P-agar between 15 and $42{ }^{\circ} \mathrm{C}$. None of the 
Table 2. Specificity of oligonucleotide probes F2son2, Stcar2, Stcar4, Stpis2, Staur and Stepi

\begin{tabular}{|c|c|c|c|c|c|c|c|}
\hline \multirow[t]{2}{*}{ Species } & \multirow[t]{2}{*}{ Strain } & \multicolumn{6}{|c|}{ Reaction with probe*: } \\
\hline & & F2son 2 & Stcar2 & Stcar4 & Stpis2 & Staur & Stepi \\
\hline \multirow[t]{2}{*}{ Group F } & $\mathrm{F}-2^{\mathrm{T}}(\mathrm{LTH} 3734)$ & + & - & - & - & - & - \\
\hline & F-8 (LTH 3735) & + & - & - & - & - & - \\
\hline \multirow[t]{10}{*}{ Group A } & $\begin{array}{l}\text { SK } 361^{\mathrm{T}} \dagger(\mathrm{DSM} \\
20501)\end{array}$ & - & + & - & - & - & - \\
\hline & SK 07 (LTH 3724) & - & + & - & - & - & - \\
\hline & SK 13 (LTH 3730) & - & + & - & - & - & - \\
\hline & 833 (LTH 3840) & - & + & - & - & - & - \\
\hline & 836 (LTH 3841) & - & + & - & - & - & - \\
\hline & LTH 18 & ND & + & - & ND & ND & ND \\
\hline & LTH 53 & ND & + & - & ND & ND & ND \\
\hline & LTH 175 & ND & + & - & ND & $\mathrm{ND}$ & ND \\
\hline & LTH 1574 & ND & + & - & ND & ND & ND \\
\hline & LTH 2102 & ND & + & - & ND & ND & ND \\
\hline \multirow[t]{6}{*}{ Group B } & SK $06($ LTH 3723) & - & - & + & - & - & - \\
\hline & SK 08 (LTH 3728) & - & - & + & - & - & - \\
\hline & SK 09 (LTH 3726) & - & - & + & - & - & - \\
\hline & SK 10 (LTH 3727) & - & - & + & - & - & - \\
\hline & SK $11^{\mathrm{T}}($ LTH 3728$)$ & - & - & + & - & - & - \\
\hline & SK $12($ LTH 3729$) \dagger$ & - & - & + & - & - & - \\
\hline S. piscifermentans & (10 strains) & - & - & - & + & - & - \\
\hline S. aureus & (10 strains) & - & - & - & - & + & - \\
\hline S. epidermidis & (8 strains) & - & - & - & - & - & + \\
\hline
\end{tabular}

ND, Not determined.

* No hybrids were obtained with DNA of other strains listed in Table 1.

$\dagger$ Strain used for construction of specific probe.

Table 3. Description of specific probes for the strains of groups $F, A$ and $B$ as well as of $S$. piscifermentans, S. aureus and S. epidermidis

\begin{tabular}{|c|c|c|c|c|}
\hline \multirow[t]{2}{*}{ Target organism } & \multirow[t]{2}{*}{ Probe } & \multirow[t]{2}{*}{ Sequence $\left(5^{\prime}-3^{\prime}\right)$} & \multicolumn{2}{|c|}{$\begin{array}{l}\text { Temperature }\left({ }^{\circ} \mathrm{C}\right) \\
\text { used for: }\end{array}$} \\
\hline & & & Hybridization & Washing \\
\hline Group F & F2son 2 & CGCCATTCTCAAGGT & 43 & 45 \\
\hline Group A & Stcar2 & ACCTTGAGAATAGCG & 43 & 46 \\
\hline Group B & Stcar4 & ACCTTGTGAATAGCG & 43 & 46 \\
\hline S. piscifermentans & Stpis2 & CGCCATTCATAAGGT & 43 & 45 \\
\hline S. aureus & Staur & AGCCTTAACGAGTACCGG & 50 & 53 \\
\hline S. epidermidis & Stepi & CGGCACTCATAAGGCTG & 50 & 52 \\
\hline Bacteria & EUB338* & GCTGCCTCCCGTAGGAGT & 43 & 45 \\
\hline
\end{tabular}

* Targeted against 16S rRNA (1).

strains grew at $8{ }^{\circ} \mathrm{C}$. After $48 \mathrm{~h}$ incubation, colonies $(0 \cdot 5-2 \mathrm{~mm}$ diameter) appeared circular, smooth, slightly raised and cream-coloured or orange (strains SK 07 and SK 13). All strains tolerated concentrations of $\mathrm{NaCl}$ up to $15 \%$.

\section{Physiological characterization}

The study of physiological characteristics supported the genotypic grouping of the strains. As shown in Table 5, strains of groups F, A and B exhibited 
Table 4. DNA similarities of strains $F-2^{\top}, F-8$, S. carnosus SK $361^{\top}$ and S. piscifermentans SK $03^{\top}$ using ${ }^{32}$-labelled DNA of strain $\mathrm{F}-2^{\top}$ as a probe

\begin{tabular}{|lccc|}
\hline Strain & $\begin{array}{c}\text { EUB338 } \\
\text { (relative signal) }\end{array}$ & $\begin{array}{c}\text { F-2 }^{\mathrm{T}} \text { probe } \\
\text { (relative signal) }\end{array}$ & $\begin{array}{c}\text { Calculated DNA } \\
\text { homology (\%) }\end{array}$ \\
\hline F-2 & 100 & 100 & 100 \\
F-8 & 99 & 97 & 98 \\
SK $361^{\mathrm{T}}$ & 102 & 59 & 58 \\
SK $03^{\mathrm{T}}$ & 83 & 42 & 51 \\
\hline
\end{tabular}

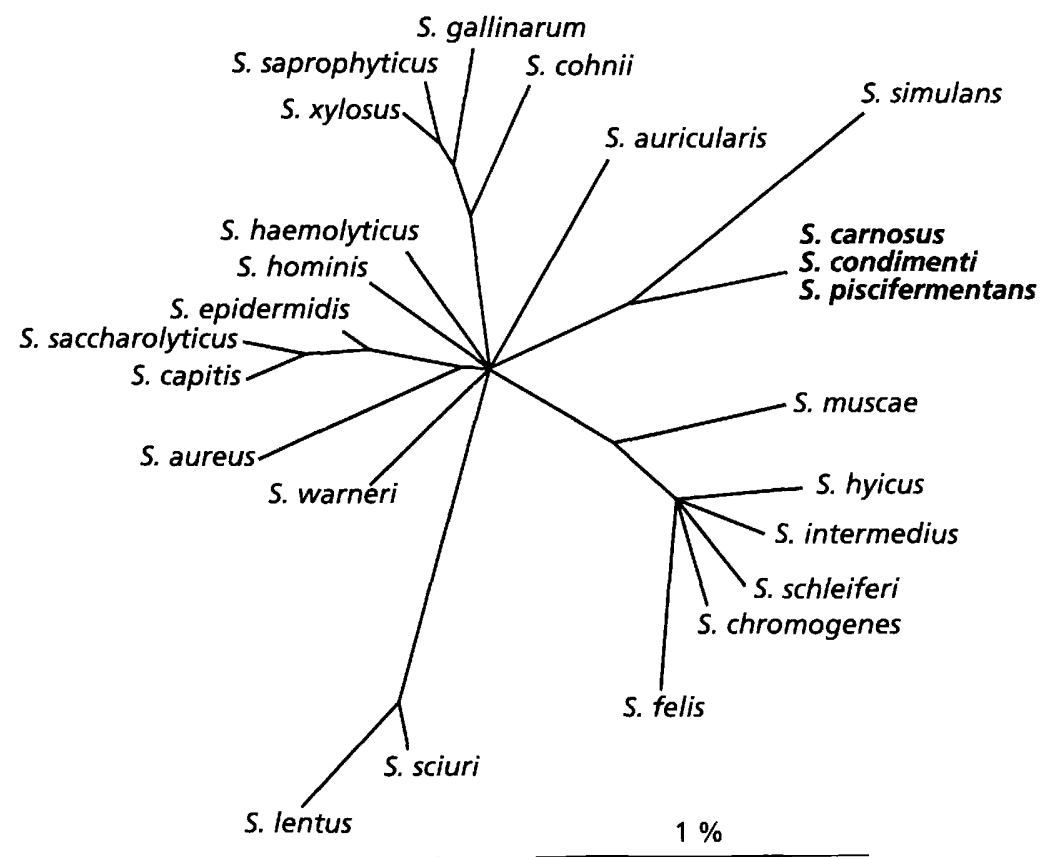

Fig. 1. 165 rRNA-based tree reflecting the phylogenetic relationships of staphylococci. The tree is based on a maximum-likelihood tree and a data set containing all available almost complete 165 rRNA sequences from staphylococci and selected reference organisms from other phylogenetic groups. For the calculations, only those alignment positions sharing identical residues in at least $50 \%$ of all staphylococcal sequences were used. The tree topology was corrected according to the results of distance matrix as well as maximum-parsimony analyses. Multifurcations indicate that a common branching order was not supported by applying alternative treeing methods. The bar indicates $1 \%$ estimated sequence divergence. catalase and arginine dihydrolase activity but no $\beta$ glucuronidase activity. They reduced nitrate to nitrite (except strain SK 09), and nitrite was also reduced as described previously (5). Acid was produced from glucose, fructose, $N$-acetylglucosamine and glycerol. All strains were susceptible to novobiocin. None of these strains produced acid from raffinose, ribose, cellobiose, arabinose and turanose. Strains assigned to group A exhibited phosphatase activity and produced acid from D-mannose and D-sorbitol. None of these characteristics was present in the strains of group B. Strains $F-2^{\mathrm{T}}$ and F-8 were allotted to group $\mathrm{F}$ and exhibited urease as well as high lipolytic activity.

\section{DISCUSSION}

Staphylococci in food, such as $S$. carnosus and $S$. piscifermentans, may exert desirable effects as components of a fermentation flora, whereas other species, for example $S$. aureus and $S$. epidermidis, are known as food poisoning organisms or potential pathogens. To develop a system for their identification and differentiation, oligonucleotide probes were designed by the comparative analysis of the large subunit rRNA primary structures of the type strains. The evaluation of the specificity of these probes revealed a genetic heterogeneity of the $S$. carnosus strains studied. Further sequence analyses of $23 \mathrm{~S}$ rRNA genes led to the design of probes that, in combination with the type strain-specific probe, allowed the detection of all strains formerly classified as $S$. carnosus. The strains could be divided into three sub-groups (F, A and B).

The strains of group $F$ were originally found in soy sauce mash and described as the new species 'Tetracoccus soyae' by Ueno \& Omata (22). However, this species was never validated. In more recent studies, these strains have been identified as $S$. carnosus (20), mainly because of their DNA-DNA similarity level of 69-72\%. However, the strains exhibited certain specific physiological characteristics, and the results of our DNA-DNA hybridization studies (51-58\% similarity) are also indicative of their separation from the species $S$. carnosus. On the other hand, the overall similarities of rRNA sequences of strains $\mathrm{F}-2^{\mathrm{T}}, S$. piscifermentans SK $03^{\mathrm{T}}$ and the corresponding sequences of strain $S$. carnosus SK $361^{\mathrm{T}}$ were rather 
Table 5. Differential characteristics of the strains of groups F, A and B and S. piscifermentans SK $03^{\top}$

$\mathbf{T}=$ Type strain $; \mathrm{ND}$, not determined; $\mathbf{w}$, weak reaction.

\begin{tabular}{|c|c|c|c|c|c|c|c|c|c|c|c|c|c|c|c|c|c|c|c|}
\hline \multirow[t]{2}{*}{ Characteristic } & \multicolumn{2}{|c|}{ Group F } & \multicolumn{10}{|c|}{ Group A } & \multicolumn{6}{|c|}{ Group B } & \multirow{2}{*}{$\begin{array}{l}\text { SK } \\
\mathbf{0 3}^{\mathrm{T}}\end{array}$} \\
\hline & $\mathbf{F}-\mathbf{2}^{\mathbf{T}}$ & F-8 & $\begin{array}{c}\text { SK } \\
\mathbf{3 6 1}^{\mathrm{T}}\end{array}$ & $\begin{array}{l}\text { SK } \\
\mathbf{0 7}\end{array}$ & $\begin{array}{r}\text { SK } \\
13\end{array}$ & $\mathbf{8 3 3}$ & 836 & $\begin{array}{c}\text { LTH } \\
18\end{array}$ & $\begin{array}{c}\text { LTH } \\
53\end{array}$ & $\begin{array}{c}\text { LTH } \\
175\end{array}$ & $\begin{array}{c}\text { LTH } \\
1574\end{array}$ & $\begin{array}{l}\text { LTH } \\
2102\end{array}$ & $\begin{array}{l}\text { SK } \\
06\end{array}$ & $\begin{array}{l}\text { SK } \\
\mathbf{0 8}\end{array}$ & $\begin{array}{l}\text { SK } \\
09\end{array}$ & $\begin{array}{l}\text { SK } \\
10\end{array}$ & $\begin{array}{l}\text { SK } \\
11^{T}\end{array}$ & $\begin{array}{l}\text { SK } \\
12\end{array}$ & \\
\hline Urease & + & + & - & - & - & - & - & - & - & - & - & - & - & - & - & - & - & - & + \\
\hline Phosphatase & + & + & $w$ & + & + & + & + & + & + & + & + & + & - & - & - & - & - & - & w \\
\hline Lipolytic activity & + & + & - & - & - & ND & ND & - & - & - & - & - & - & - & - & - & - & - & + \\
\hline Aesculin hydrolysis & - & - & - & w & w & - & - & - & - & - & - & - & - & - & - & - & - & - & + \\
\hline \multicolumn{20}{|l|}{ Acid from: } \\
\hline D-Galactose & + & w & + & - & + & - & - & - & - & - & - & - & - & - & - & - & - & - & + \\
\hline D-Mannose & + & + & + & + & + & + & + & + & + & + & + & + & - & - & - & - & - & - & - \\
\hline Lactose & + & w & + & - & - & + & + & + & + & + & + & + & - & - & - & - & - & - & + \\
\hline Maltose & - & - & - & - & - & - & - & - & - & - & - & - & - & - & - & - & - & - & + \\
\hline Sucrose & $\mathrm{w}$ & w & - & - & - & - & - & - & - & - & - & - & - & - & - & - & - & - & + \\
\hline Turanose & - & - & - & - & - & - & - & - & - & - & - & - & - & - & - & - & - & - & + \\
\hline Trehalose & + & + & + & + & + & - & - & - & - & - & - & - & - & + & + & + & + & + & + \\
\hline D-Melezitose & - & - & - & - & - & - & - & - & - & - & - & - & - & - & - & - & - & - & + \\
\hline Mannitol & + & + & + & - & - & + & + & + & + & + & + & + & - & - & - & - & - & - & - \\
\hline D-Sorbitol & + & + & + & + & + & + & + & + & + & + & + & + & - & - & - & - & - & - & - \\
\hline Growth at $45^{\circ} \mathrm{C}$ & + & - & - & - & - & - & - & - & - & - & - & - & - & - & - & - & - & - & + \\
\hline Growth at $\mathrm{pH} 5$ & + & w & - & w & - & + & + & + & $\mathrm{w}$ & + & + & + & w & $\mathrm{w}$ & + & + & + & + & w \\
\hline Growth on $15 \% \mathrm{NaCl}$ & + & + & + & + & + & + & + & + & + & + & + & + & + & + & + & + & + & + & + \\
\hline \multicolumn{20}{|l|}{ Susceptibility to $\left(\mu \mathrm{g} \mathrm{ml}^{-1}\right)$ : } \\
\hline Lysozyme $(400)$ & - & - & - & - & - & - & - & - & - & - & - & - & - & - & - & - & - & - & - \\
\hline Lysozyme (1600) & - & - & - & - & - & - & - & - & - & - & - & - & - & - & - & - & - & - & - \\
\hline Lysostaphin (200) & + & + & + & + & + & + & + & + & + & + & + & + & + & + & + & + & + & + & + \\
\hline
\end{tabular}

high $(>98.9 \%)$. The comparative rRNA sequence analysis at this level of phylogenetic relatedness can only provide differentiating information and is not sufficient to be used for species definition. It is accepted (19) that the superior method for phylogenetic investigation at or below the species level is the quantitative hybridization analysis of genomic DNA. The quantitative DNA-DNA reassociation studies confirmed a close relationship of the $\mathrm{F}$ group strains $(98 \%$ similarity), which were clearly separated from the type strains of $S$. carnosus and S. piscifermentans. Taking into account the recommended threshold value of $70 \%$ genomic DNA relatedness as a limit for species definition (23), together with the characteristic epigenetic properties, e.g. urease and lipolytic activity (Table 5), the strains of group $F$ represent a new species. We propose that the strains of this group should be placed in a new Staphylococcus species, Staphylococcus condimenti.

The evaluation of the probe specificities also revealed a heterogeneity among the remaining strains of $S$. carnosus. According to their high levels of DNA-DNA similarity $(>73 \%)$ reported by Tanasupawat et al. (20), these strains have to be grouped in one single species. There exist characteristic differences among these strains in their physiological properties as well as in their reaction with specific $23 \mathrm{~S}$ rRNA-directed probes. Based on these results, we propose to place the strains of group B in a new subspecies of Staphylococcus carnosus Schleifer and Fischer 1982, Staphylococcus carnosus subsp. utilis. In accordance with Rule 40 of the International Code of Nomenclature of Bacteria, the strains of group A are placed in the subspecies Staphylococcus carnosus subsp. carnosus. This grouping is consistent with the results obtained in studies of the potential of strains of $S$. carnosus to form biogenic amines and to exhibit haemolytic activities (4). It was observed that the strains of group B were virtually free of that potential, whereas in strains of group $A$, these activities were frequently present.

\section{Description of Staphylococcus condimenti sp. nov.}

Staphylococcus condimenti (con.di.men'ti. L. n. condimentum spice; L. gen. n. condimenti of the spice).

Cells are Gram-positive cocci (diameter $1 \mu \mathrm{m}$ ), facultative anaerobic, non-motile, non-spore-forming and occur in pairs, short chains and small clusters. Colonies on P-agar are usually opaque, circular and slightly raised, with entire margins. After $48 \mathrm{~h}$ incubation, colonies are cream-coloured and 1-2 $\mathrm{mm}$ in diameter. They exhibit catalase, urease, arginine dihydrolase, nitrate reductase, nitrite reductase, $\beta$ galactosidase, phosphatase and lipolytic activity. Aesculin is not hydrolysed; no $\beta$-glucuronidase activity is detectable. Acid is produced from glucose, fructose, mannose, galactose, trehalose, mannitol, sorbitol and glycerol. Acid is not produced from raffinose, ribose, cellobiose, turanose and arabinose. Lecithinase and coagulase activity is not detectable. Strains grow at 15 and $42{ }^{\circ} \mathrm{C}$ and on $\mathrm{P}$-agar containing $0.5-15 \% \mathrm{NaCl}$. Sensitive to lysostaphin $\left(200 \mu \mathrm{g} \mathrm{ml}^{-1}\right)$ and resistant to lysozyme (400 and $1600 \mu \mathrm{g} \mathrm{ml}^{-1}$ ). Variable characteristics are shown in Table 5. DNA G $+\mathrm{C}$ content is $35 \cdot 2-36 \mathrm{~mol} \%$. MK-7 is the major menaquinone, and MK-6 or MK-6 and MK-8 are the minor mena- 
quinones. Strains were isolated from soy sauce mash. Strain F-2 $2^{\mathrm{T}}\left(=\mathrm{DSM} 11674^{\mathrm{T}}\right)$ is the type strain, and its characteristics are those described above. Its $\mathrm{G}+\mathrm{C}$ content is $35.2 \mathrm{~mol} \%$. MK-7 is the major menaquinone; MK-6 is the minor menaquinone. The sequences of the $16 \mathrm{~S}$ and $23 \mathrm{~S}$ rRNA have EMBL accession numbers Y15750 and Y15755. Strain F-8 (= DSM 11675) is a reference strain that exhibits different physiological characteristics. This strain does not grow at $45^{\circ} \mathrm{C}$, has a $\mathrm{G}+\mathrm{C}$ content of $36 \mathrm{~mol} \%$, MK-7 as the major menaquinone and MK-6 and MK-8 as the minor menaquinones.

\section{Description of Staphylococcus carnosus subsp. utilis subsp. nov.}

Staphylococcus carnosus subsp. utilis (ut.ti'lis L. adj. utilis useful).

Cells are Gram-positive cocci (diameter $1 \mu \mathrm{m}$ ), facultative anaerobic, non-motile, non-spore-forming and occur predominantly in pairs and small clusters. Colonies on P-agar are usually opaque, circular and slightly raised, with entire margins. After $48 \mathrm{~h}$ incubation, colonies are cream-coloured and 0.5-1.5 mm in diameter. They exhibit catalase, arginine dihydrolase, nitrate reductase (except strain SK 09) and nitrite reductase activity. Aesculin is not hydrolysed; $\beta$ galactosidase, phosphatase and $\beta$-glucuronidase activity is not detectable. Acid is produced from glucose, fructose, trehalose, mannitol and glycerol. Acid is not produced from mannose, maltose, galactose, melezitose, lactose, mannitol, sorbitol, sucrose, raffinose, ribose, cellobiose, turanose and arabinose. Lecithinase and coagulase activity is not present. The strains grow at 15 and $42{ }^{\circ} \mathrm{C}$ and on P-agar containing $0.5-15 \%$ $\mathrm{NaCl}$. They are sensitive to lysostaphin $\left(200 \mu \mathrm{g} \mathrm{ml}^{-1}\right)$ and resistant to lysozyme (400 and $1600 \mu \mathrm{g} \mathrm{ml}^{-1}$ ). Variable characteristics are shown in Table 5. The DNA $G+C$ content is $34 \cdot 8-37 \cdot 1 \mathrm{~mol} \%$. They contain MK-7 as the major menaquinone and MK-6 or MK-6 and MK-8 as the minor menaquinones. Isolated from fermenting fish and shrimp sauces. Strain SK $11^{\mathrm{T}}$ (= DSM $11676^{\mathrm{T}}$ ) is the type strain, and its characteristics are those described above. The $\mathrm{G}+\mathrm{C}$ content is $34 \cdot 8 \%$. MK-7 is the major menaquinone. Strain SK 09 (= DSM 11677) is a reference strain that exhibits different characteristics. This strain does not exhibit nitrate reductase activity. MK-7 is the major menaquinone; MK- 6 and MK- 8 are the minor menaquinones.

\section{ACKNOWLEDGEMENTS}

We thank M. Schramm, J. Hinrichs and M. Kranz for excellent technical assistance.

\section{REFERENCES}

1. Amann, R. I., Ludwig, W. \& Schleifer, K. H. (1995). Phylogenetic identification and in situ detection of individual microbial cells without cultivation. Microbiol Rev 59, 143-169.
2. De Man, J. C., Rogosa, M. \& Sharpe, M. E. (1960). A medium for the cultivation of lactobacilli. J Appl Bacteriol 23, 130-135.

3. Hammes, W. P. \& Knauf, H. J. (1994). Starters in the processing of meat products. Meat $S c i$ 36, 155-168.

4. Hammes, W. P., Bosch, I. \& Wolf, G. (1995). Contribution of Staphylococcus carnosus and Staphylococcus piscifermentans to the fermentation of protein foods. $J \mathrm{Appl}$ Bacteriol (suppl.) 79, 76S-83S.

5. Hartmann, S., Wolf, G. \& Hammes, W. P. (1995). Reduction of nitrite by Staphylococcus carnosus and Staphylococcus piscifermentans. Syst Appl Microbiol 18, 323-328.

6. Hertel, C., Ludwig, W. \& Schleifer, K. H. (1992). Introduction of silent mutations in a proteinase gene of Lactococcus lactis as a useful marker for monitoring studies. Syst Appl Microbiol 15, 447-452.

7. Ikuta, S., Takagi, K., Bruce Wallance, R. \& Itakura, K. (1987). Dissociation kinetics of 19 base paired oligonucleotideDNA duplexes containing different single mismatched base pairs. Nucleic Acids Res 15, 797-811.

8. Kloos, W. E., Tornabene, T. G. \& Schleifer, K. H. (1974). Isolation and characterization of micrococci from human skin, including two new species: Micrococcus lylae and Micrococcus kristinae. Int J Syst Bacteriol 24, 79-101.

9. Knauf, H. J., Vogel, R. F. \& Hammes, W. P. (1992). Cloning, sequence, and phenotypic expression of kat A which encodes the catalase of Lactobacillus sake LTH 677. Appl Environ Microbiol 58, 832-839.

10. Liebl, W., Ehrmann, M., Ludwig, W. \& Schleifer, K. H. (1991). Transfer of Brevibacterium divaricatum DSM 20297 'Brevibacterium flavum' DSM 20411, 'Brevibacterium lactofermentum' DSM 20412 and DSM 1412, and Corynebacterium lilium DSM $20137^{\mathrm{T}}$ to Corynebacterium glutamicum and their distinction by rRNA gene restriction patterns. Int J Syst Bacteriol 41, 255-260.

11. Ludwig, W. \& Strunk, O. (1996). ARB, Software environment for sequence data. Available under http://www.mikro.biologie.tu-muenchen.de/

12. Ludwig, W. \& Schleifer, K. H. (1992). Bacterial phylogeny based on $16 \mathrm{~S}$ and $23 \mathrm{~S}$ rRNA sequence analysis. FEMS Microbiol Rev 15, 155-173.

13. Ludwig, W., Brockmann, E., Beimfohr, C., Hertel, C. Jacobsen, B. \& Schleifer, K. H. (1995). Nucleic acid based detection systems for genetically modified bacteria. Syst Appl Microbiol 18, 477-485.

14. Ludwig, W., Kirchhoff, G., Klugbauer, N. \& 13 other authors (1992). Complete 23S ribosomal RNA sequences of Grampositive bacteria with low DNA G + C content. Syst Appl Microbiol 15, 487-501.

15. Montel, M.-C., Talon, R., Cantonnet, M. \& Fournand, J. (1992). Identification of Staphylococcus from French dry sausage. Lett Appl Microbiol 15, 73-77.

16. Sambrook, J., Fritsch, E. F. \& Maniatis, T. (1989). Molecular Cloning: a Laboratory Manual, 2nd edn. Cold Spring Harbor, NY : Cold Spring Harbor Laboratory.

17. Schleifer, K. H. \& Fischer, U. (1982). Description of a new species of the genus Staphylococcus: Staphylococcus carnosus. Int J Syst Bacteriol 32, 153-156.

18. Springer, N., Ludwig, W., Drozanski, V., Amann, R. \& Schleifer, K. H. (1992). The phylogenetic status of Sarcobium lyticum, an obligate intracellular parasite of small amoebae. FEMS Microbiol Lett 96, 199-202. 
19. Stackebrandt, E. \& Goebel, B. M. (1994). Taxonomic note: a place for DNA-DNA reassociation and 16S rRNA sequence analysis in the present species definition in bacteriology. Int J Syst Bacteriol 44, 846-849.

20. Tanasupawat, S., Hashimoto, Y., Ezaki, T., Kozaki, M. \& Komagata, K. (1991). Identification of Staphylococcus carnosus strains from fermented fish and soy sauce mash. $J$ Gen Appl Microbiol 37, 479-494.

21. Tanasupawat, S., Hashimoto, Y., Ezaki, T., Kozaki, M. \& Komagata, K. (1992). Staphylococcus piscifermentans sp.

nov., from fermented fish in Thailand. Int $J$ Syst Bacteriol 42, 577-581.

22. Ueno, T. \& Omata, S. (1961). On the anaerobic halotolerant and halophilic bacteria in soy sauce mash. 1. Taxonomic studies. J Ferment Technol 36, 360-370 (in Japanese).

23. Wayne, L. G., Brenner, D. J., Colwell, R. R. \& 9 other authors (1987). International Committee on Systematic Bacteriology. Report of the ad hoc committee on reconciliation of approaches to bacterial systematics. Int $J$ Syst Bacteriol 37, 463-464. 